УДК $782.1+783.2$

\title{
К. Немиенко
}

\section{ВТІЛЕННЯ ЕЛЕМЕНТІВ ПРАВОСЛАВНИХ ТАЇНСТВ \\ І БОГОСЛУЖБОВИХ ПОСЛІДУВАНЬ В ОПЕРНОМУ МИСТЕЦТВІ (НА ПРИКЛАДІ «СКАЗАННЯ ПРО НЕВИДИМИЙ ГРАД КІТЕЖ І ДІВУ ФЕВРОНІЮ» М. РИМСЬКОГО-КОРСАКОВА)}

Стаття присвячена розгляду втілення елементів православних таїнтв та різних богослужбових послідувань в опері М. Римського-Корсакова «Сказання про невидимий град Кітеж і діву Февронію». Зіставляються драматургічнів та семантичні особливості богослужебних дій та тексту опери.

Ключові слова: православне богослужіння, літургія, опера, драматургія опери, символ.

Інтерес до православної богослужебно-співецької традиції та їі ремінісценцій у інших жанрових сферах музичного мистецтва займає значне місце серед досліджень сучасних музикознавців. Можна припустити, що саме церковний спів понад усе відповідає національній природі музичних уявлень про духовне. Національна культура може трактуватись як сукупність символів, вірувань, переконань, цінностей, норм поведінки, які характеризують духовне життя певної нації. Жанрові й формотворні (структурно-композиційні) властивості богослужінь, їх музична i, особливо, службово-ритуальна сторони завжди залишаються ведучими, що пояснюється тим, що саме вони визначають стосунки між словесними текстами і їх «проспівуванням» - музичною інтонацією. За багатовікову історію Православ’я у даній жанровій сфері склалися не лише структурні форми богослужінь, але і певні мелодійні строфи, розспіви, які роблять впізнанним навіть положення служби в річному або седмичному колі Тіпікону.

Питання про зв'язок церковних співів із загальними феноменами, об'єктами і цілісними явищами культури придбало особливу актуальність, оскільки у даному контексті констатується й осмислюється важливість культури як літургійного феномена. Композиторський досвід у галузі літургії показує, наскільки межі богослужебно-співецьких жанрів допускають «позаособистісну» правильність». Жанр має свою власну волю, більше власную, ніж авторська» [4, с. 57].

(C) Немченко К., 2014 
Прийняте наприкінці Х століття християнство князем Володимиром поклало початок впровадження в слов'янскую культуру візантійської богослужбової практики з багатим символізмом візантійського богослужіння. Дійсно, поняття «символи» і «символізм» стали практично синонімами візантійської літургії. Здійснення богослужіння за Уставом є загальною і основною структурою в літургійному житті Церкви. Що таке Устав можна відчути з самого кореня цього слова, що містить в собі ідею встановленності, впорядкованості. В Уставі дуже багато всіляких нюансів і моментів, які необхідно розглядати в історичному аспекті розвитку богослужбової практики. Цим займається літургійне богослов'я або його скорочений варіант, літургіка, вивчаючи яку можна відчути чудову структуру церковної служби, iї динаміку, закони ії розвитку, зміст, вкладений в ії̈ структуру. Цим питанням присвячені такі книги: А. С. Кашкін. Православне богослужіння; Настільна книга священнослужителя (Том 1); В. Розанов. Богослужбовий Устав Православної Церкви; Прот. к. Нікольський. Посібник до вивчення уставу богослужіння православної церкви; Н. Сільченко. Практичний посібник при вчиненні парафіяльних треб; Ієромонах Корнилій (Аношин). Практичний порядок православного богослужіння; М. С. Красовіцька. Літургіка тощо.

Однією із основоположних констант богослужіння є Таїнства.

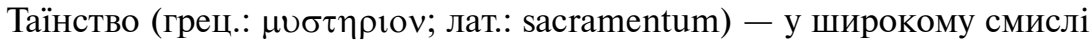
щось сокровенне, таємне, особливе таємне дійство; в Церкві видиме священнодійство, яке за допомогою обряду повідомляє віруючій лю-

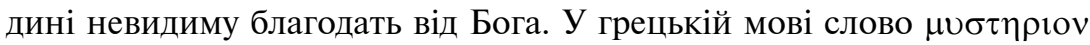

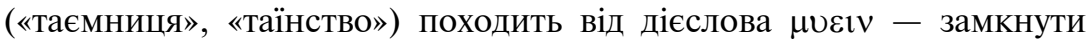

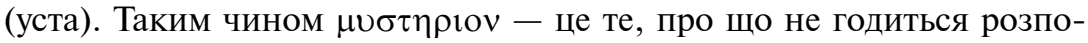
відати. Це слово здавна мало релігійний зміст, на відміну, наприклад,

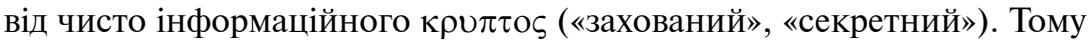
словом $\mu \nu \sigma \tau \eta \rho เ o v$ позначалися релігійні культи і обряди, закриті для сторонніх. Християнські таїнства вважаються встановленими самим Ісусом Христом і покликані змінити не зовнішнє, а внутрішне життя людини. Вони покликані змінювати людину зсередини на краще, повідомляючи їй схожість зі Спасителем. У Православ'ї сім таїнств:

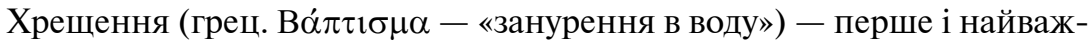
ливіше християнське таінство. Через хрещення людина стає членом Церкви; Причастя або Євхаристія - з'єднання з Христом через прийняття вина і хліба; шлюб або вінчання - християнський подружній союз чоловіка й жінки, укладений через священнодійство в релігійній 
громаді, згідно з установленим порядком; покаяння або сповідь являє собою визнання віруючим гріхів перед Богом у присутності священика, який, в даному випадку, будучи тільки свідком, від імені Iсуса Христа спеціальними дозвільними словами відпускає гріхи всім, хто щиро розкаялися; миропомазання або конфірмація (др.-греч. Хрí $\sigma \mu \alpha$, лат. Chrisma) - священнодійство в християнських церквах, через яке віруючому подаються дари Святого Духа, які зміцнюють його в духовному житті; єлеєосвячення або соборування - згідно 3 православним вченням, віруючому прощаються гріхи, які він забув чи не встиг сповідати; священство або висвячення в священицький сан, в якому через святительське рукоположення на вірно обраного сходить Святий Дух і поставляє його здійснювати Таїнства і пасти стадо Христове.

У багатьох композиторських творах Таїнства знайшли своє відображення як у сюжеті, так і в структурно-конструктивному задумі твору і в музичній його частині. Розглянемо втілення елементів православних таїнств і богослужбових послідувань в опері М. Римського-Корсакова «Сказання про невидимий град Кітеж і про діву Февронію».

«Сказання про невидимий град Кітеж і діву Февронію» є надзвичайно цікавою і унікальною за концепцією оперою не лише у творчості М. Римського-Корсакова, але і у всьому світовому музичному мистецтві. У ній поєднуються досконала краса і абсолютна гармонія, що відображає закони світобудови та втілює сутність душі православної людини. У ній знайшла своє відображення історія від минулого до майбутнього, нерозривно пов'язана з християнськими цінностями, заснована на щирій абсолютній вірі, яка рятує в найважчих випробуваннях. Опера, подібно іконі, є відображенням видимого і невидимого світів, заглядає в самі глибини людського серця. Сам М. Римський-Корсаков називав $\dddot{1 i ̈ ~ « л і т у р г і и ̆ н о ю ~ о п е р о ю » . ~ У ~ н і и ̆ ~ з н а-~}$ йшли відображення не тільки богослужіння, Таїнства християнської церкви, але й ідея катарсису, через явище Апокаліпсису.

Як вказував сам композитор, вже при самому зародженні задуму опери ії сюжет був пов'язаний з двома джералами: перша розповідала про Кітеж, друга - про св. княгиню Февронію Муромську [6]. Переказ про святу входить до складу Житій святих, написаних Димитрієм Ростовським (пам'ять св. Благовірних князя Петра і княгині Февронії (у чернецтві Аавіда і Єфросинії) святкується Православною церквою 25 червня). В опері лінія Февронії розроблена дешо інакше, ніж у ііі 
житії. Згідно з оперним лібрето, заснованим більше на відомому народному переказі, ніж на житії Димитрія Ростовського, Февронія за походженням своїм була простою поселянкою, сестрою древолаза (ім'я его не названо; за народною легендою, вона була донька «древолазца бортника» з села Ласкавого Рязанської губернії).

Февронія, як стає відомим з ії житія, була одружена з князем Петром, другим сином Муромского князя Юрія Володимировича (в опері цей князь назван Юрій Всеволодович, а княжич - Всеволод Юрійович). Для лібрето були використані «Кітежский літописець» в різних редакціях, повість про Февронію Муромську, літописи і оповідання про татарське нашестя, «Слово» Серапіона, єпископа Володимирського, повість про Юліанію Лазаревську, повість про Горе-безталання, історичні, ліричні, обрядові (весільні) пісні, билини, духовні вірші. Усе це вказується в передмові до партитури В. І. Бельським: «Але, як побачить кожен, хто знайомий з пойменованими пам'ятками, для обширного і складного сценічного твору розсіяних в цих джерелах рис занадто недостатньо. 3 цієї причини були необхідні численні і далекосяжні доповнення, які, проте, автор розглядав лише як спробу по окремих обривках і натяках вгадати ціле, приховане в глибині народного духу, по одних випадково збереженних в джерелах частковостях - світогляд діючих осіб, по подробицях зовнішньої обстановки та ін. відтворити інші подробиці невідомої в цілому картини. У підсумку, може бути, у всьому творі не знайдеться жодної дрібниці, яка так чи інакше не була навіяна рисою якого-небудь сказання, заговору або плоду російської народної творчості [2].

Дослідник ескізів, чернеток сценарію і лібрето, М. Арановський, зазначає, що «йшов відбір найбільш суттєвого, відповідного меті», що «вся історія створення лібрето говорить про прагнення авторів побудувати самостійну і притому цілісну етико-релігійну концепцію» [1, c. 104]. Аналіз матеріалів дозволяє йому зробити висновок про те, що «лібрето стає приводом для появи на його полях музичних ескізів і для розробки драматургії опери в цілому. Композитор співвідносить з вербальним рядом (сюжетними положеннями, сценами, вчинками героїв, їх характерами) ряд їхніх музичних еквівалентів, переводячи на мову музики позамузичні сутності [1, с. 109]. Робота над сюжетноконцептуальною стороною випереджала процес створення тематичної основи опери.

«Кітеж» являє собою монументальне історичне полотно, оперу, в якій органічно поєдналися насамперед два роди мистецтва - 
епос і драма. Разом з тим найважливіша стильова особливість твору пов'язана з його релігійним змістом, соборністю, наявністю безлічі сакрально-символічних змістів, містеріальних асоціацій, що не раз відзначалося і вченими, і виконавцями. У сюжетній композиції опери, в тексті лібрето, в музичній драматургії простежується двоплановість: перший план - зримий, сценічний, другий план - незримий, символічний, який весь час є присутнім і робить основний вплив на перший план. Це важливий фактор, що пояснює статичність, ораторіальність опери, виправдовує ії споглядальний характер.

Концепцію опери необхідно розглядати з точки зору деякої єдності різних верств змісту, що зумовлює дослідження літературного шару, лібрето, авторських вказівок, ремарок, сюжетно-фабульної драматургії, де, безумовно, виявляється багато відповідностей, алюзій з християнським аспектом даної опери. Один із основоположних шарів релігійного змісту «Кітежа» пов'язаний з відтворенням в лібрето житія святих Петра і Февронії Муромських. Інший - $з$ відображенням церковних православних служб (всеношної, акафісту, літургії (Б. Асафьєв, М. Рахманова, Т. Щербакова)) і православних свят (А. Парин). Третій - розкривається через призму Євангелія і Одкровення святого Іоанна Богослова (Л. Серебрякова). Розкриття складного контексту змісту допомагає таким чином зрозуміти і художньо-концепційний задум твору, його драматургію і композицію.

У житії зазначено, що молода пара жила в мирі, любові, благочестії, не забуваючи молитву, храм Божий, роздаючи щедрі милості Господа ради. Февронія своїми руками годувала й напувала мандрівників, одягала жебраків, лікувала хворих, відвідувала в'язнів у темниці, невпинно перебуваючи в пості, лагідності, смиренні і страху Божому. Ці моральні і духовні якості розкриваються М. Римським-Корсаковим вже на самому початку опери. У «Спогадах В. В. Ястребцева» (27 березня 1903) вказується: «На питання Всеволода, хто вона така, хрещеного чи звання, або ж «болотіца» (тобто русалка), і чи буває вона коли в церкви, Февронія відповідає, що церква від них далеко, але що в цьому вона не бачить особливого горя, так як церква Божа скрізь і Бог всюди. Треба тільки самому робити добро і любити все живе і тоді життя людини зробиться прекрасним, земля перетвориться на рай, на деревах зацвітуть золоті та срібні квіти і кругом заспівають райські птахи. (Такі її віра, іiї мрії)» [8, с. 282].

Важливе зіставлення у тексті опери виникає з послідування вечірні та утрені на Всенічному бдінні, про що вказував Б. Асафьєв та бага- 
то інших дослідників, але дуже важливим, на наш погляд, є втілення рис акафіста у першій картині третьої дії опери.

Акафіст, у старообрядців акафісто (грец. О Ака́ $\theta \imath \sigma \tau \varsigma \varsigma$ ' $\mu \nu о \varsigma$, також неседален, неседальная пісня, тобто «пісня, яку співають, не сідаючи, стоячи»), - жанр православної церковної гімнографії, споріднений кондаку в первинному значенні терміна. «Кондаком» раніше називався згорток паперу, на якому з обох сторін щось написано. Відмітимо, що акафіст - це спів, який складається з кількох розділів та містить стислу інформацію про житіє святого або головні риси торжества. Завершуються вони словами, які потім співаються в кінці всіх ікосів, наступних після них. Композиційна і метрична побудова акафіста своєрідна. Акафісту предписан зачин - так званий проімій (від грец. кукулион - капюшон, тобто що накриває строфи).

Спів акафіста в храмах або монастирях відпочатку пов'язаний з діалогічностю. Священиком зазвичай читається перша половина ікосу або кондака, другу половину, як правило, підхоплює група молільників (чернецтва, іноків, парафіян). У кондаках парафіяни зазвичай співають рефрен Аллілуйя, в ікосах - вітання починаються зі слова Радуйся. Вважається, що найсильніше основне прохання відбувається при читанні останнього кондака (13), який читається тричі і є колінопреклонною молитвою. Саме ця діалогічність, антифонність, структурне поєднання питання й відповіді, які є характерною ознакою богослужбового послідування акафісту, також виявляються як найважливіші засоби першої картини третьої дії опери.

Тут присутні соліст і хор - свого роду священик і парафіяни. Ключовою фігурою є князь Юрій, який позиціонується як збірний образ, поєднуючий різні іпостасі. Він постає як глава Великого Кітежа, посивілий мудрий старець. Крізь призму його образу проглядається постать преподобного Сергія Радонезького, благословляючого Дмитра Донського, а також ченців з його пастви і російських воїнів на Куликівську битву. Деякі дослідники вказують на аналогію між князем Юрієм і Досифєєм з «Хованщини», де йдеться не про подібності в музичному рішенні, а на рівні подвижництва [1, с. 115].

Лунає трикратне моління: тричі князь Юрій звертається до народу - «Браття! До Владичиці починайте благати, Кітежа заступниці небесної» і тричі повторюється славнозвісний хор «Чудна небесна цариця, наша ти заступниця святая, милістю великої не залиш. Кітеж град покрий своїм покровом. Змилуйся небесна цариця, ангелів пішли нам в оборону» (заснована на знаменної темі). Саме цей хор, що 
втілює таїнство сокровенної молитви, викликає асоціації з 13 кондаком акафіста Пресвятій Богородиці:

О, Всехвальна Мати, родшая всіх святих Святійше Слово! Нинішне прийнявши приношення, Від усякої визволи напасти всіх.

Антифонність, як принцип цієї картини, продовжується і в подальшому: репліках княжича Всеволода і відповідях дружини, вигуках князя Юрія і відповідях кітежан. Втілення ідеї таїнства Євхаристії та його богослужбового вчинення у Літургії можемо простежити у драматургії четвертого дії. Літургія (обідня) є кульмінацією всього, що відбувається у храмі. Головною богословською ідеєю Літургії $є$ з'єднання з Христом через таїнство Причастя. Тому одним з найважливіших моментів четвертої дії, де виникає думка про Літургію, можна вважати зустріч Февронії з Привидом княжича Всеволода в першій картині дії. Пояснюється це головною думкою княжича та 3 його діями, коли він виймає кусень хліба і подає його Февронії, використовуючи про цьому вираз «вічна радість» як слідство вкушання «хлібу». Це пряма вказівка в опері на таїнство Євхаристії, літургійне значення тих подій, які відбуваються. Важливими також є і слова княжича: «Ось прийми до зміцнення». Саме насамперед через таїнство причастя людина зміцнюється у вірі, осягає іiі сокровенне єство, зміцнюється і духовно, і тілесно. Тут вибудовується паралельно і інший глибинний сенс - наречений-привид з'являється перед Февронією і як би у вигляді очікуваного Небесного Жениха-Хріста. На Таємній Вечері Ісус приносив у жертву Тіло і Кров свою (безкровна жертва Христа), символізуючи їх в хлібі і вині, і тим самим роблячи учасників трапези - своїх учнів-апостолів - причетними своєї духовної сутності і залучаючи їх до обраних та вірних (Єв. від Матв., гл. 26, вірш 26-29).

Цікаві міркування у зв'язку з цим фрагментом дії висловлені Л. Серебряковою: «В Свангелії від Луки <..> годування хлібом виступає саме як «розпізнавальний знак» Христа, який з'явився учням на третій день по розп'ятті, перед вознесінням, тобто саме як знак з'явлення розп'ятого і воскреслого Христа, за яким «Він був впізнаний ними в ламанні хліба» (Лук. 24: 15-16; 30:31; 35)» [7, с. 97].

Образ Пасхи, Великодньої Літургії стає домінуючим у фіналі «Кітежа». «Свято Світлого Христового Воскресіння проступає в трі- 
умфування Граду з його «вічною радістю» [3, с. 312]. «Кітеж» закінчується радісним передзвоном церковних дзвонів, що символізують торжество життя над смертю, торжество безсмертя. Фаворське світло заливає все і стає головним носієм сакрального, божественного, що підтверджують авторські ремарки: «Хмари розсіюються. Град Кітеж чудесно преображен. Успенський собор і княжий двір поблизу західних воріт. Високі дзвіниці, багаття на стінах, вигадливі терема і повалуші з білого каменю і кондового дерева. Різьба прикрашена перлами; розпис синього, попелястого і синьо-червоного кольору, 3 усіма переходами, які бувають на хмарах. Світло яскраве, блакитнобіле і рівне з усіх боків, як би що не дає тіні» (початок другої картини 4-ї діï), і далі - «двері собору розчиняються, являючи невимовне світло».

Таким чином, євангельські мотиви, втілені в певній подієвій стороні, і його сутнісне світорозуміння незмінно отримали відображення в опері. Висхідний шлях до світла в «Кітежі» відображає найважливішу ідею, шо уособлює смислову домінанту твору, іiі стрижень, що полягає у донесенні ідеї духовного пошуку, прагнення людини до досконалості і духовної гармонії, спраги пізнання і отримання істини, прагнення до накопичення духовних багатств. Саме до цього прагнула Февронія, чий образ є образом-ідеєю, образом - філософською системою, бо в ньому сконцентровано все найкраще і досконале. За словами М. Лосського, «вищий ступінь досконалості особистості існує в тому випадку, якщо вона, відповідно до заповіді Христа, живе любов'ю до Бога, більшою, ніж до себе, і любов'ю до всіх інших людей, равною любові до себе. Іншими словами, цілком досконала та особистість, яка любить лише абсолютні цінності, здатні задовольняти всі істоти і що йдуть на користь усім. Такі особи суть члени Царства Божого: вони удостоєні обоження за благодаттю, тобто зводяться Богом на ступінь такої близькості до себе, що беруть участь в повноті його буття і причетні всім його досконалостям, як якби стали <...> синами Божими. Будучи «чисті серцем», вони удостоюються споглядати Бога лицем до лиця, i, отже, «радість їхня у Господі» безмірно перевершує все, що відомо нам з земного досвіду» [5, с. 326].

\section{СПИСОК ЛІТЕРАТУРИ}

1. Арановский М. Г. К истории создания «Китежа». Эскизы, черновики сценария и либретто / М. Г. Арановский // Музыка России: от средних веков до современности : Сб. статей. - М., 2004. - Вып. 2. - С. 101-116. 
2. Вельский В. Замечания к тексту. 1905 г./ В. Вельский // Н. А. РимскийКорсаков. Сказание о невидимом граде Китеже и деве Февронии. Партитура. Полн. собр. соч. - М. : Музгиз, 1962. - Т. 14 а.

3. Ларин А. В. Хождение в невидимый град : Парадигмы русской классической оперы / А. В. Ларин. - М. : Аграф, 1999. - 464 с.

4. Лихачев Д. С. Исследования по древнерусской литературе / Д. С. Лихачев. - Л. : Наука, 1986. - 405 с.

5. Лосский Н. Бог и мировое зло. Основы теодицеи / Н. Лосский ; [ред. А. П. Поляков, П. В. Алексеев, А. А. Яковлев]. - М. : Республика, 1994. $432 \mathrm{c}$.

6. Римский-Корсаков Н. Летопись моей музыкальной жизни / Н. Римский-Корсаков. - 9-е изд. - М. : Музыка, 1982. - 440 с.

7. Серебрякова Л. А. «Китеж»: откровение «Откровения» / Л. А. Серебрякова // Музыкальная Академия. - 1994. - № 2. - С. 90-106.

8. Ястребцев В. В. Николай Андреевич Римский-Корсаков. Воспоминания...1886-1908 : в 2 т. / В. В. Ястребцев. - Л. : Музгиз, 1960. - Т.2. 18981908. $-634 \mathrm{c}$.

Немиенко Е. Воплощение элементов православных таинств и богослужсебных последований в оперном искусстве (на примере «Сказания о невидимом граде Китеже и деве Февронии Н. Римского-Корсакова). Статья посвящена рассмотрению воплощения элементов православных таинств и различных богослужебных последований в опере Н. Римского-Корсакова «Сказание о невидимом граде Китеже и деве Февронии». Сопоставляются драматургические и семантические особенности богослужебных действий и текста оперы.

Ключевые слова: православное богослужение, литургия, опера, драматургия оперы, символ.

Nemchenko E. Implementation of elements of orthodox sacraments and liturgical persecution in opera (for example, "The legend of the invisible city of Kitezh and the maiden Fevronia» by N. Rimsky-Korsakov). The article is devoted to the implementation of elements of Orthodox sacraments and liturgical posliduvan in various opera by N. Rimsky-Korsakov's «Legend of the Invisible City of Kitezh and the Maiden Fevronia». Spivstavlyayutsya dramatic and semantic features liturgical action and the text of the opera.

Keywords: Orthodox worship, liturgy, opera, drama, opera character.

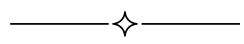

